\title{
Feminist Edebiyat Eleştirisi ve Hatice Bilen Buğra'nın Mal Sahibi Adlı Hikâyesinin İncelenmesi
}

\author{
Havvaana KARADENIZ \\ Kırşehir Ahi Evran Üniversitesi, Türk Dili Bölümü, Kırşehir \\ havvaanakaradeniz@gmail.com \\ ORCID ID: https://orcid.org/0000-0003-3423-887X
}

\begin{tabular}{lrr} 
Araştırma Makalesi & DOI: 10.31592/aeusbed.589693 \\
\hline Geliş Tarihi: 09.07.2019 & Revize Tarihi: 29.11.2019 & Kabul Tarihi: 29.11.2019
\end{tabular}

\section{Atıf Bilgisi}

Karadeniz, H. (2019). Feminist edebiyat eleştirisi ve Hatice Bilen Buğra’nın Mal Sahibi adlı hikâyesinin incelenmesi. Ahi Evran Üniversitesi Sosyal Bilimler Enstitüsü Dergisi, 5(2), 284-298.

\section{ÖZ}

Okur merkezli kuramlardan biri olarak değerlendirilen feminist edebiyat eleştirisi; okur olarak kadına yönelik eleştiri, yazar olarak kadına yönelik eleştiri, psikanalitik ve Marksist eleştiri olmak üzere disiplinler arası bir yaklaşımla kadın sorununa eğilen bir eleştiridir. Feminist edebiyat eleştirisi, ataerkil bir toplumun yansıması olarak toplumdaki ve edebiyattaki hâkim erkek bakış açısını yansıtan değerleri sorgulayarak kadının toplum içindeki yerine ve karşı karşıya olduğu sorunlara dikkat çekmeyi amaçlar. Feminist eleştiri, kadın erkek ilişkilerinde sürekli olarak erkeğin baskın çıkmasını eleştirir. Bu ilişki içerisinde kadının, genellikle erkek tarafından seçilmiş bir yaşam biçimine boyun eğen durumda oluşuna vurgu yapar. Yapılan çalışmalar doğrultusunda kadının birçok yönden ezilmişliği ortaya konur ve bu bilinç oluşturulmaya çalışılır. Feminizm hareketi ile kadınlar iş sahasında, eğitimde, iletişimde, toplum ve aile içinde erkeklerle eşit yasal haklara sahip olmaya başlar. Böylece kadınlar yaşamın her sahasında sesini duyurmayı başarır. Feminist edebiyat eleştirisi ile de zihinlerde yer edinen erkek bakış açılı okuma şeklinin/algısının değişmeye başladığına dikkat çekilir. Çalışmada ilk olarak edebiyat eleştiri yöntemlerinden biri olan "feminist edebiyat eleştirisi" hakkında bilgi verilmiş ve daha sonra Hatice Bilen Buğra'nın Mal Sahibi hikâyesi bu eleştiri yöntemine göre incelenmiştir.

Anahtar Kelimeler: Feminist edebiyat eleştirisi, kadın kimliği, Hatice Bilen Buğra.

\section{An Examination of Feminist Literary Criticism and The Story Mal Sahibi (Owner) by Hatice Bilen Buğra}

\begin{abstract}
As a reader-centred theory, feminist literary criticism addresses the woman question with an interdisciplinary approach including the criticism of women as readers, criticism of women as writers, and psychoanalytic and Marxist criticism. Feminist literary criticism questions the values based on the dominant male perspective in society and literature as a reflection of patriarchal society and tries to raise concern about the place and challenges of women in society. Feminist criticism expostulates the continual male prevalence in man-woman relationship. It points out the fact that woman is generally selected and bows to the lifestyle selected by her man. Studies of this kind try to raise awareness about the fact that women are battered in many ways. Owing to the Feminist movement, women began to have equal rights with men in employment, education, communication, society, and family. They managed to speak up in every field of life. Feminist literary criticism points out that reading styles or perceptions from the male point of view have been changing. This paper gives information about the "feminist literary criticism" as a method of literary criticism at first and aims to examine the story titled as Mal Sahibi by Hatice Bilen Buğra according to this method of criticism. Keywords: Feminist literary criticism, woman identity, Hatice Bilen Buğra.
\end{abstract}

\section{Giriş}

\section{Feminist Edebiyat Eleştirisi}

Kadının yalnızca gerçek yaşam sahnesinde değil, aynı zamanda roman, şiir, tiyatro gibi daha birçok eserde aşağılandığı, horlandığı, hiçe sayıldığı ve erkek egemen bir düzenin hâkim olduğu görülür. Bu bakımdan feminist eleştiri, edebî türlerde kadının ele alınış şeklini ve kadına karşı bu yaklaşımı ortaya çıkarmak amacıyla başlar ve kısa sürede kadına yönelik başka sorunlara da dikkat çekmeyi başarır. 
"Toplumda kadının haklarını çoğaltma, erkeğinkiler düzeyine çıkarma, eşitlik sağlama amacını güden düşünce akımı, kadın hareketi” (Türk Dil Kurumu, 2009, s. 687) olarak tanımlanan feminizm, 1960'lardan itibaren genel feminist hareketi ile ilintili olarak gelişme gösterir. "Başlangıçta erkeklerin sahip oldukları haklara kavuşmak biçiminde masumca taleplerle başlayan feminist hareket giderek bir ideolojiye dönüştü." (Kolcu, 2010, s. 358). İlk hareket noktası erkek yazarların, eserlerinde kadına bakış açısını ve kadını ele alış şeklini ortaya koymak olur. Ancak daha sonra bilim, teknoloji ve eğitimdeki gelişmelerle beraber feminist eleştiri, kadın yazarları inceler, onların yazma geleneğini tespit etmeye çalışır. Bugün gelinen noktada ise erkek egemen toplumsal yaşamda iletişim aracı olan dilin ve söylemlerin; kadını hor gören, yok sayan bir araç olarak kullanıldığı sonucuna ulaşılır, dikkatler "kadın söylemi" ve "kadın sorunu" üzerine çekilmeye çalışılır. Feminist eleştiriyi "harekete geçiren şey; cinsiyet, kimlik ve dil arasındaki ilişkinin sorgulanması yoluyla dil, edebî biçimler, kadınların ve erkeklerin tini arasında güçlü ve cinsel olarak dışa vurumcu bir ilişkiyi yeniden biçimlemekti." (Humm, 2002, s. 38).

Eagleton'a (2011, s. 160) göre feminizm, siyasi sorunların ortaya çıtığı gibi bir kampanya değil; bireyi, toplumu ve siyasi yaşamı her açıdan sorgulayan ve şekillendiren bir boyuttur. Kadın hareketinin amacı, kadınların yalnızca erkeklerle eşit güç ve statüye sahip olmaları değildir; bütün bu güç ve statülerin, toplumsal düzenin sorgulanmasıdır. Burada önemli olan kadınların sosyal yaşamda daha aktif olmalarıyla dünyanın daha iyi olmasından ziyade, insanlık tarihi dişileştirilmezse dünyanın ve mutlu bir yaşamın devamlılığının pek uzun sürmeyeceğidir. Bu nedenle kadına, bir özne/birey olarak yaklaşılmalı, ona kadın olma bilinci ve imkânı sunulmalıdır. Bu bilinç, davranışın yanı sıra kadına karşı yeni bir dil ve söylem oluşturularak da inşa edilir. Çünkü "erkekler ve kadınlar sıklıkla farklı bir söz dağarcığına sahiptirler ve bu söz dağarcığını farklı türden cümlelerde kullanmaktadırlar." (Humm, 2002, s. 22).

Showalter (Humm, 2002, s. 33) ve Moran (1994, s. 229) feminist eleştiriyi, okur olarak ve yazar olarak kadına yönelik feminist eleştiri olmak üzere iki kısımda ele alırken Kolcu (2010, s. 358383) feminist eleştirmenlerin edebiyata yönelik dört ana yaklaşımından bahseder: okur olarak kadına yönelik feminist eleştiri, yazar olarak kadına yönelik feminist eleştiri, psikanaliz açısından feminist eleştiri, Marksist/Sosyalist açıdan feminist eleştiri.

\section{Okur Olarak Kadına Yönelik Feminist Eleştiri}

Bu yöntem ile bir metnin kadın okur tarafindan okunması veya okuyucu ister kadın ister erkek olsun kadın okur gözüyle algılanması anlaşılır. Kadın okur, sadece cinsiyet yönünden yapılan bir ayrım değildir. Bu ayrım, yaşam süresince kültürel yönden kazanılan kadın olma bilincidir. $\mathrm{Bu}$ nedenle eserin yorumlanmasında okuyucunun bilgi birikimi, eğitim düzeyi, yaşadığ 1 dönem ve içinde bulunduğu toplumsal düzen önemli bir rol oynar. "Feminist eleştirinin ilk ve en önemli kazanımı, cinsiyet kalıplarına edebî biçimin önemli bir özelliği olarak dikkat çekmesidir. Feminist eleştirinin ikinci ve eşdeğerdeki önemli kazanımı ise bu türden önemli kalıpların 1srarla yeniden üretilmelerinin nedenlerini vermesidir. Bir üçüncü ve utkulu başarı da kadınlara ait edebiyatın kaybolmuş veya göz ardı edilmiş örneklerinin ve kadınların bugüne kadarki sayısız metinlerinin keşfedilmesidir." (Humm, 2002, s. 27). Okur olarak kadına yönelik feminist eleştirinin amaçları; erkek yazarların eserlerine kadın okur bakış açısı ile bakarak bu eserlerde sergilenen cinsel ideolojiyi, kadın imgelerini, kadın kimliğini, kadın söylemini, kadın tipini ve kadının hem birey hem de toplum bazında ezilmesini/sömürülmesini, mevcut kültürün içinde kadının konumunu, kalıplaşmış kadın tiplerini belirlemek ve bütün bunları feminist yönden eleştirmektir.

$\mathrm{Bu}$ tarz eleştirinin ilk örneklerini veren ve Marksist bir yaklaşım ile ataerkil toplumu eleştiren Simone de Beauvior, kadının politik ve ekonomik alanda ezilmesini altyapı, sanat ve edebiyat yapıtlarında aşağılanmış bir şekilde yansıtılmasını da üstyapı şeklinde belirler (Akt. Moran, 1994, s. 229-230). Kadının bu şekilde ezilmesi, aşağılanması ve yalnızca cinsiyeti ile öne çıkarılması erkek egemen bir toplum düzeni içinde kadını baskı altında tutmak ve erkeğin her zaman üstün olduğunu göstermek için geliştirilen bir yöntemdir. De Beauvoir kadın ve erkeğin yapı bakımından farklı özellikler taşıdığını belirtir. "De Beauvoir'e göre kadın ve erkek arasındaki fiziksel farklılıklar ancak 
toplumsal düzenlemelerde anlam taşır; bu açıdan kadın ve erkek arasındaki farklılığı biyolojik özellikler açıklar ama belirlemezler.” (Humm, 2002, s. 66). Böylece kadının pek çok açıdan ezilmişliği kategorize edilir.

Okur olarak kadına yönelik feminist eleştiride herhangi bir sanat eserine bir kadın ile bir erkeğin bakışının, eser karşısında vereceği tepkinin veya eserden alacağı haz duygusunun aynı olmayacağına dikkat çekilmeye çalışılır. Kadın ile erkeğin biyolojik yönden cinsiyet ayrımı üzerinde durulmasından ziyade, kadın ve erkeğin toplumdaki yeri üzerinde durulur. Çünkü ataerkil bir toplum düzeninde erkeğin; dünyaya, nesnelere, olaylara, varlıklara kendine has ve egemen bir bakışı varken kadın, bu düzen içerisinde ikinci veya üçüncü plana itilmiş, ötelenmiş, içinde bulunduğu topluma ve kendisine yabancılaşmış bir nesne konumundadır. Bir başka ifade ile kadın doğurganlığı ile ön plana çıkan, çocuğun bakımını sağlayan, hiçbir sorununu gün yüzüne çıarmayan bir nesnedir.

Kadını bir okur olarak kabul eden feminist edebiyat kuramının temel felsefesi, erkekler tarafından yazılan eserlerin tabiatı itibariyle erkek egemen düşünceyi yansıtması ve bu eserlerde cinsiyet ideolojisinin belirgin bir şekilde ön plana çıkmasıdır. Bu tür eserlerde erkek yazarlar, kadınların ne hissettiğini ne düşündüğünü dikkate almadan kadını, doğrudan kendi bakış açıları ile yansıtır ve bir heykeltıraş gibi yeniden şekillendirir. Erkek yazarların eserlerinde kadın kahramanlara nasıl baktığı incelenirse "romanın cinsiyeti var mıdır" meselesi de açıklığa kavuşturulmuş olur.

Moran (1994, s. 231-232), Gilbert ve Gubar'1n “canavar" ve "evdeki melek" olarak adlandırdığı kadın tiplerini “ölümcül kadın” ve "kurban” olarak adlandırır. Moran’a göre kurban kadın tipi namuslu, alçakgönüllü, uysal, masum, kendini evine/kocasına/çocuklarına adayan, genç kız ve kadın tipidir. Bu kadın tipi erkek yazarların idealize ettiği, erkek egemenliğine severek, isteyerek boyun eğen, güzel ve melek huylu kadınlardır. Türk edebiyatında Şemsettin Sami'nin Taaşşuk-ı Talât ve Fitnat adlı romanın kahramanı Fitnat, Namık Kemal'in Intibah romanındaki Dilaşup, Samipaşazade Sezai'nin Sergüzeşt'indeki Dilber, Ahmet Mithat Efendi'nin Felatun Bey ve Râkım Efendi'sindeki Canan adlı karakterler kurban kadın tipinin örnekleri olarak gösterilir.

Ölümcül kadın tipi ise bağımsızlığa-özgürlüğe düşkün, kişisel çıkarlarını ön plana çıkaran, erkek egemen bir toplumda otoriteye başkaldıran ve kendine biçilen hayat tarzını kabullenmeyen kadınlardır. Bu kadın tipi okura bir şeytan gibi sunulan, her türlü entrika, hile, yalan ve hatta cinayete başvuran kadınlardır. Bu ölümcül kadın tipi Intibah romanındaki Mahpeyker, Nabizade Nazım'ın Zehra'sı, Yeryüzünde Bir Melek romanındaki Arife tipleriyle örneklendirilebilir.

Edebî eserlerde kadın, bu şekilde kategorize edilerek psikolojik açıdan baskı altına alınmaya ve üzerinde güç uygulanmaya çalışılır. Bunun için kadın roman/hikâye kurgusunun içinde bir oyuncak gibi kullanılır ve yansitılır.

"Dişilik doğaldır ve doğuştandır, kadınlık ise eğitim ve terbiye sonucunda sonradan kazanılır. Ataerkil oyun bu kavramları özdeşleştirmekle oynanır." (Moran, 1994, s. 232) Kadının doğuştan sahip olduğu ve biyolojik yönünü belirten dişilik ile toplumsal ve kültürel yaşantıların belirlediği kadınlık rolü, yazar tarafından bir oyun şeklinde özdeşleştirilir. Böylece kadının gerçek hayat ile edebî eserlerdeki durumu arasındaki ilişkiye vurgu yapılır. Okur olarak kadına yönelik feminist eleştirinin ilk evresinde erkek yazarların, eserlerinde kadını ele alış, işleyiş şekli, kadın hakkındaki düşünceleri ortaya konmaya çalışılmış ve kadının ideolojik açıdan ele alındığı görülmüştür.

\section{Yazar Olarak Kadına Yönelik Feminist Eleștiri}

$\mathrm{Bu}$ yaklaşımda kadınların yazar olarak erkek yazarlardan farklı söylem ve dillerinin olup olmadığı üzerinde durulur. Erkek egemenliği ile şekillenmiş edebiyat dünyasında kadın yazarların işi bir hayli güçtür. Bu nedenle kadın yazarlar, erkek egemen edebiyat dünyasında eserlerini tıpkı erkek yazarlar gibi yazmaya başlar, hatta bu süreçte kendi kimliğini gizleyerek erkek adları kullanır ve eserlerinde erkek yazarların kurallarını uygular. Bu durum kadınların bir edebî eser yazmak için erkek yazarlardan ve ataerkil toplumdan âdeta bir izin/onay almak zorunda hissettiklerini gösterir. 
“...başlangıçta aşılması gereken bir erkek egemen edebiyat alanı vardır. Kadın yazarlar erkeklerin döşediği raylar üzerinden bir edebiyat yapacaklarına göre onların yarattığı sistematiğe teslim olmuşlar demektir." (Kolcu, 2010, s. 364). Bu nedenle sınırlarını, erkeklerin belirlediği erkek egemen edebiyat dünyasının öncelikle yıkılması gerekir.

Kadın yazarlar bu toplumun içinden yetişmiş insanlar olduğuna göre bu insanların kadın olarak çektiği acılar ve beklentiler ortaktır. Bu nedenle "kadın edebiyatı, öncelikle kadınlar için, kadınlar tarafından yazılan ve kadınları anlatan eserler" (Argunşah, 1999, s. 35) olarak ortaya çıkar. $\mathrm{Bu}$ bakımdan çekilen acıların ve beklentilerin eserlere yansıma biçimleri de aynı ya da benzer olacaktır. Örneğin aşk temasının işlendiği bir eserde aşk teması, kadın figürü üzerinden işlenir. $\mathrm{O}$ hâlde erkek egemen edebiyat alanı içerisinde bir kadın yazar da aşkı, tıpkı erkek yazarlar gibi onların şiir anlayışını ve söylemlerini kabul ederek anlatır. Ataerkil toplumlarda “... gücü temsil ettiği için erkek etken, kadın edilgendir." (Kolcu, 2010, s. 369). Kadın yazarın bu durumu ve duruşu, bir nevi erkek egemen sanat anlayışına çaresiz bir şekilde teslimiyettir. Kadın yazarların dünyaya bakış açısı, yaşam şekli, yaşam karşısındaki duruşu, maruz kaldıkları sömürü ve ezilmişlik gibi nedenler kadınlar arasında ortak veya benzer bir birliktelik oluşturur. Bütün bu nedenler aynı zamanda kadınların bu dünyayı ve hayatı erkeklerden farklı algılamasına yol açar. Bundan dolayı kadın yazarların kendine özgü yazma geleneği oluşur, bu gelenek kadınların öteden beri aynı baskılara, davranış ve tutumlara maruz kalmaları etkisiyle şekillenir.

$\mathrm{Bu}$ noktada kadın sanatçıların her şeyden önce yapmaları gereken şey, kadınların kendi kimliklerini ve birey olarak var olduklarını ortaya koyabilecek yeni bir anlatım dilini/söylemini, üslubunu oluşturmak ve geliştirmektir. Böylece kadın yazaraların eserleri "Şahsî sızlanmaların edebiyatı olmak suçlamasından kurtularak belki de düşünce özgürlüğüne, kendine güvene, kendi üstüne kapanmış bir anlatımdan çok, dışa dönük ve hayatla daha ilgili bir edebiyata geçilecektir." (Argunşah, 1999a, s. 86). Sanat dünyasında var olan erkek egemen dil anlayışı yalnızca kadının duygu ve düşünce dünyasını kendine has bakış açısı ile yansıtmakla kalmaz, aynı zamanda dış dünyadaki kavramları, eşyayı, nesneleri ve yaşama dair her şeyi kendi bakış açısı ile verir.

Amerikalı eleştirmen E. Showalter A Literature of Their Own adlı kitabında İngiliz roman tarihindeki kadın yazarları inceler ve 1840'lardan günümüze kadar uzanan zaman diliminde kadın yazarların "kadını yazma" şeklini üç evreye ayırarak izah eder (Akt. Moran, 1994, s. 234-235). Buna göre birinci evrede (1840-1880) kadın yazarlar, erkek yazarları taklit ederler. Erkek yazarların kadın hakkındaki düşüncelerini kabul eder ve eserlerini bir erkeğin ağzından yazıyormuş gibi göstererek takma erkek adları ile yayımlarlar. 1880-1920 yılları arasını kapsayan ikinci evrede kadın yazarlar artık erkek yazarları taklit etmezler. Kadın yazarlar, erkek bakışı ile yazma geleneğini bilinçli bir şekilde bırakarak feminist bir duruşla kadınların uğradığı haksızlıkları, baskı altında ezilişlerini yüksek sesle dile getirmeye başlarlar. Kadınların bu güçlü seslenişi, bu durumu âdeta bir dava hâline getirdiklerinin göstergesidir. 1920'den günümüze kadar olan üçüncü evrede ise erkek yazarları taklit etmeyi bir tarafa bırakan kadın yazarlar, içinde bulundukları ezilmişlik duygusunu anlatmaktan da vazgeçerek artık kadını sanatsal açıdan ele alır ve kadındaki estetik yönleri keşfetmeye ve yansıtmaya çalışırlar. Yapılan bütün bu çalışmalar kadına "edebî kimlik" oluşturulmasını sağlar.

19. yüzyıldan itibaren erkek egemen toplum düzeninin kadına biçtiği rolü aşan kadın yazarlar, kadının toplum içinde birey olarak görmezden gelinmesi düşüncesini yıkarak kendilerine özgü bir yaşam tarzının ve roman yazma geleneğinin kapılarını aralarlar. Bu yaklaşım ontolojik açıdan değerlendirildiğinde kadının doğurganlığa ve ezilmişliğe karşı bu yeni duruşunun yanında toplumdaki mevcut kadın algısına da karşı bir duruş olarak görülür.

Ataerkil toplumlarda üstün değerler erkeği, aşağı değerler ise kadını ifade eder. Bu durumu değiştirmek için kadın söylemine eğilen ve kadın sorununu ele alan bir "ifade şekli"ne yeni bir "dil"e Moran'ın (1994, s. 239) ifadesi ile "kadınca dil, ataerkilce dili yıkmayı hedefleyen, ikili karşıtlıklar mantığına yer vermeyen, bir başkaldırı diline" ihtiyaç vardır. Derrida (Moran, 1994, s. 237-239), ikili karşıtlıkların bünyesinde bulunan hiyerarşiyi yani, birincisi ikincisine üstündür, yargısını yıkmaya çalışır. Böylece erkek/kadın, ruh/beden, akıl/doğa gibi ikincisinin birincisine nazaran eksik ve kusurlu 
olduğu şeklinde ifade edilen ikili karşıtlıklar, yapısöküme uğratılarak bu unsurların eşitlik, benzerlik ve farklılıkları ortaya konmaya çalışılır. Bu noktada ikili karşıtlıkların yapısöküme uğratılmasıyla beraber geleneksel değerlerin yerini yeni değerler alırken yeni bir dil ve ifade şekli de oluşturulmaya çalış1ır. Böylece metinde bilinçli bir şekilde dışlanmış olan kadın, özne şeklinde konumlandırılarak metne dâhil edilir.

\section{Psikanaliz Açıdan Feminist Eleştiri}

$\mathrm{Bu}$ yaklaşım, kadını hem okur hem de yazar olması itibari ile Psikanalitik açıdan ele alır. $\mathrm{Bu}$ kuramın temeli Freud, Jung, Adler ve diğer psikologların araştırmalarına dayanır. "Psikanalitik eleştiri feminizme geniş bir alan kazandırmıştır. Feministler arzuyu, cinsel kimliği ve dilbilimsel yapıları sorgulamak için psikanalizi kullanarak edebiyattaki cinsiyet hiyerarşisini ve toplumdaki cinsiyet hiyerarşisini yapıbozuma uğratabilirler." (Humm, 2002, s. 188). Freud, kendi psikanalitik yaklaşımında erkek karşısında kadını; eksik, yetersiz ve ikinci sınıf bir nesne olarak görür.

Freud, kadını erkek egemen bir toplum düzeninde ataerkil aile içinde bir nesne olarak görür. Kadın hayatta kalabilmek için baba, kardeş veya eş gibi bir figüre ihtiyaç duyar. Freud kadının bu durumunu Elektra kompleksi şeklinde ifade eder. Duygu Asena'nın Fügen ya da Arayış öyküsünde Fügen, beş evliliğinin sonunda gerçekleştirdiği son evlilik ile mükemmel evliliği bulur. Fügen, bu arayışı sonucunda "tatlı ve şefkat" sembolü olarak tanımladığı eşini baba idolü olarak görür. Fügen'in, evlendiği son eşini mükemmel olarak görmesi belki de bilinçdışında başka bir erkekte göremediği "babalık" figürünü bulmasında yatar. Bu da Freud'un Elektra kompleksiyle açıklanabilir. Aynı şekilde Halit Ziya Uşaklıgil'in Aşk-ı Memnu romanında anne-kız arasında çatışmaya neden olan Adnan Bey, Bihter için hayallerindeki eşten çok eksikliğini hissettiği ve şefkatine kavuşacağı bir baba konumundadır. Bu da yine Freud'un Elektra kompleksiyle izah edilebilir.

Psikanalitik açıdan feminist eleştiri "anneler, babalar ve çocukların psişik ilişkisi; cinsellik ve cinselliğin dile getirilişi arasındaki ilişki; yazarlar ve okurların paylaştığı kimliğin değişkenliği”" (Humm, 2002, s. 48) gibi gizil kalmış pek çok eğilimi ve kodları çözümlemeye çalışır. Sosyal, kültürel ve bilimsel alanlardaki gelişmelerle beraber bireyler ve gruplar arasındaki ilişki de değişir. Bu bağlamda anne-baba ve çocuklar arasındaki ilişki modern psikanalizin ışığında incelenir, “...günlük hayatın duygusal ve düşünsel dilinin, vaka ve psişik, nevrotik durumların eserlere yansıyıp yansımadığı" (Kolcu, 2010, s. 371) araştırılır. Araştırma sonucunda elde edilen bulgular yazar, okur ve sanat eserlerindeki kahramanların ruh hâllerini, bilinçdışında cereyan eden olayları eleştirel bakımdan çözümlemek için kullanılır. Böylece elde edilen bulgular yazarın öz yaşamının derinliklerinde kalmış, özel ve gizli bilgileri gün yüzüne çıkarır ve anlamlı hâle getirir. Günlük hayatta sorgulanamayan birçok olay ve olgu edebî eserler aracılığı ile psikanalitik açıdan incelenir. Psikanaliz "...öznenin kişiselliğinin gizli bölümlerine geçit sağlayabilecek kısımlarına odaklanır.” (Humm, 2002, s. 170). Kadınsal imgeleri ortaya koymak, anlamlandırmak ve sorgulamak için psikanaliz açıdan feminist eleştiri önemli bir unsurdur.

\section{Marksist/Sosyalist Açıdan Feminist Eleştiri}

Fransız yazar Simone de Beauvior'a göre kadının ekonomik ve siyasal bakımdan ezilmesi bir alt yapı kurumu; sanat, edebiyat ve estetik alanda ezilmesi, görmezden gelinmesi de üst yapı kurumu olarak görülür. Kadın sosyal, kültürel, sanatsal ve ekonomik bakımdan ezilen ve sadece ona biçilen hayatı yaşayan bir varlıktır (Akt. Kolcu, 2010, s. 379).

Marksizm, günlük yaşam içerisinde kadını maddi olarak yaptıkları ya da yapmadıkları işle tanımlamaya çalışır. "Marksist ve sosyalist feminizm kesin bir terim değildir. Marksist feminizm geleneksel olarak edebî üretimin maddi şartlarına bakarken sosyalist feministler kadınların hayatlarının ayrıntılarına ve kadınların alternatif değerlerine odaklanırlar.” (Humm, 2002, s. 115) Marksistlerin sanatı ortaya koymak için başvurduğu bu yöntem aslında sınıf çatışmasına dayanır. Bu bağlamda kadınlar öteden beri iş gücü olarak görülerek onlardan proleter bir sınıf oluş̧turulmak istenir. Erkek egemen anlayış içerisinde kadın hem iş gücü hem de cinsel ideoloji bakımından alınıp satılan 
bir varlık gibi görülür ve bu tutum altında sömürülür. "Kadını bir mal ve sömürü aracı olarak gören kapitalist-burjuva düzeninin yıkılmasıyla kadın da özgürlüğe kavuşacaktır.” (Kolcu, 2010, s. 381). Kadınların yapacağı şey, bu konuda erkeklerle çatışmak yerine onların egemen olduğu dünyaya dâhil olarak etkin bir konuma gelmektir.

Kadının içinde bulunduğu ataerkil aile yapısı, gelenek ve görenekler, örf ve âdetler, toplumsal ahlak kuralları üst yapıyı ve Marksist ideolojiyi oluşturur. Bu bakımdan kadının, toplum içinde kadın olma kimliğini kazanıp var olabilmesi için sosyal, kültürel, ekonomik ve eğitim bakımından erkeklerle eşit haklara erişebilmesi gerekir. "Marksist teoriye göre, kadının ekonomik anlamda erkeğe bağımlı hâle gelmesi, onu diğer sosyal alanlarda da erkeğe bağımlı hâle getirmiştir. Zaten ataerkil yapıların varlığından bu yana hâkim düşünce de budur. Kadının bağımlı yaşamı onu 'ikinci cins' olarak belirleyen temel faktördür." (Aktaş, 2013, s. 64). Ekonomik anlamda özgürlüğü olmayan kadın hem özel hem de kamusal alanda kendini yabancılaşmış ve ötekileşmiş hissederek kendi kimliğini inşa etmekte zorlanır.

\section{Hatice Bilen Buğra'nın Mal Sahibi Hikâyesinin Feminist Eleştiri Açısından İncelenmesi}

Çalışmanın birinci bölümünde feminist edebiyat kuramı hakkında bilgi verilmiş ve "yazar olarak kadına yönelik feminist eleştiri" başlığında kadın yazarların, kadına ve kadın sorununa bakışında erkek yazarlara göre farklı yaklaşım geliştirebilecekleri ortaya konmuştur. Hatice Bilen Buğra'nın Mal Sahibi adlı hikâyesinin, yazar olarak kadına yönelik feminist eleştiri, psikanaliz açıdan feminist eleştiri ve Marksist/Sosyalist açıdan feminist eleştiri bakımlarından ele alınmaya uygun bir hikâye olduğu görülür. Bu hikâyede kadının, gerçek hayattaki durumu, olduğu gibi edebî esere yansıtılır. Çalışmanın bu bölümünde Hatice Bilen Buğra'nın bir kadın yazar olarak Mal Sahibi adlı hikâyesinde kadın sorununa nasıl yaklaştı̆̆ feminist edebiyat kuramı doğrultusunda açıklanmaya çalışılmıştır.

Öykü ve roman yazarlığı ile bilinen Hatice Bilen Buğra, eserlerinde şehirde ve özellikle kırsal kesimde ezilen, ötelenen ve görmezden gelinen kadınların sorunlarını dile getirir. Kadını eğitim, iş, evlilik, anne, çocuk bakımı, ailedeki konumu, aşağılanma, yaşam düzeyi gibi pek çok açıdan ele alarak kadının sorunlarına ışık tutar ve öyküleriyle âdeta kadınların sesi olur. Toplumun kadına bakışını ve kadının da toplum algısını gerçekçi bir şekilde yansıtır. Hatice Bilen Buğra yazdıklarını hayatın bir parçası, bir gerçeği olarak tanımlar. Bu bakımdan onun hikâyeleri gündelik yaşamda karşılaşılan ancak farkına varılmayan kadın sorunlarına dikkat çekmektir. Normal gibi algılanan sürecin aslında ne derece anormal olduğunu toplumun bilincine varmasını sağlamaktır.

Evlendiği adamın kendisini terk etmesiyle üç çocuğu ile geçim derdine düşen bir kadının anlatıldığ Mal Sahibi adlı hikâye, kadın anlatıcının birinci şahıslı anlatımı (ben anlatıcı) ile tahkiye edilir. Böylece kadın bakış açısı ile birinci ağızdan ataerkil aile yapısı, toplum baskısı ve erkek rolü ile ilgili okura bilgi verilir. Anlatıcı, olayları sanki okuyucuyla dertleşiyor gibi anlatır, aslında anlatı, kadının başından geçen olayları paylaştı̆̆ı bir iç dökümüdür. Öyküde toplumsal düzenin kadını bünyesinde barındırmadığı görülür. Anlatıcı, hikâyesine kocasının kendisini terk etmesi üzerine üç çocuğu ile tek başına kaldığı, ezilmişlik duygusu içinde olduğu bilgisini okura vererek başlar: "Kocam evi terk ettiği vakit büyük oğlum yedi yaşındaydı; kızım dört, küçük oğlum da iki..." (Buğra, 1992, s. 28).

Anlatının bu şekilde başlaması vurdumduymaz ve bencil erkek tipi ile karşılaşılacağına dair ilk ipucudur. Bu erkek, karısının ve üç çocuğunun nasıl geçineceklerini hiç düşünmeden onları terk eder; ancak kadın bu durumu çoktan kabullenir ve kocasının onu terk edişine şaşırmaz: "Ne kavga etmiştik, ne dövüş. Bir sabah işe uğurladım, akşam eve gelmedi. Sen şimdi, başına bir iş geldi sanacaksın, ama yoo... öyle değil. Hiç şaşmadım gelmeyişine, merak bile etmedim.” (Buğra, 1992, s. 28).

Kadın anlatıcının "Sen şimdi, başına bir iş geldi sanacaksın" ifadesiyle başından geçenleri okuyucuyla paylaştığı görülür. Hikâyede kadının, toplum nazarında değersizliği ve bir de kadın, köyde 
yaşıyorsa kıymetinin yok denecek kadar az olduğu vurgulanır. Feminist eleştirinin üzerinde durduğu en önemli meselelerden biri, kadının öncelikli görevinin erkeklere hizmet etmek olduğunu öğreten toplumsal süreç ile mücadeledir. Erkek egemen toplum düzeni içerisinde kadının yaşam alanını sınırlayan geleneksel yapı, kadını, anne ve ev kadını olma rolü ile baskı altına alırken dış dünyanın sunduğu sosyo-kültürel imkânlardan da uzaklaştırır. Bu uzaklaştırma, bilinçli yapılan bir davranıştır. Bir kızın evlenmesi, bir nesnenin alınıp satılmasından farksızdır. Kadının, evlendikten sonra kocası ve onun ailesi ile yaşaması ve kendisinden beklenenleri yerine getirmesi gerekir. Kadın elde edilene kadar kıymetlidir, elde edildikten sonra ise yüzüne bakılmaz. Hikâyeden alınan şu bölüm bu durumu gözler önüne serer:

"Alana kadar yandı tutuştu benim için. Benden kıymetlisi yoktu o zaman. Gelir, bütün gün, evimizin yanındaki kuyunun başında nöbet tutardı; dışarı çıkayım da beni görsün... Sonunda meramını yerine getirdi. Hoş, köylük yerde evlenmek nedir? Bir akşam gelip babamdan istediler beni, birkaç akşam sonra da onların evinin bir köşesine bir yatak serdiler bizim için; evlendik!” (Buğra, 1992, s. 28).

Mal Sahibi adlı hikâyede Anadolu kadınının evlilik sorunu da görülür. Bu sorun kendini henüz bilinçli bir şekilde tanımayan bireyin kadın olması, dahası çocuk yaşta anne olması gerçeği okuyucunun dikkatine sunulur. Burada, kız çocuklarının en azından kendi ayakları üzerinde durabilene kadar evlendirilmemesi gerektiği ve çocuk gelin olmadan önce onların çocukluklarını yaşamalarına müsaade edilmesi gerektiği vurgulanır. Çiftin evlenme serüveninden de anlaşıldığı gibi kadına karşısındaki erkeği tanıma, onu benimseme ve sevme hakkı verilmez. Kadın, bir birey olarak bir parçanın yarısı olarak görülmez; alınıp satılan bir nesne gibi görülür. Ayrıca mevcut kültürün içinde kadının konumu, evliliği ve bu evlilikte kadına yalnızca cinsel kimlik ile bakılmasına vurgu yapılır. Feminist eleştiri, kadınlara birtakım siyasi olanaklar sunulmadan önce bireyin tercihlerinin dikkate alınmadığı, yalnızca ona biçilen kimliği yaşamak zorunda kaldığı noktasına dikkat çeker. Öztürk (2014)'ün ifadesiyle erkek seçen, kadın ise seçilendir; karar erkeklerin, tahammül kadınların payına düşendir, genel itibariyle. Kadının; sosyal, kültürel, sanatsal ve ekonomik bakımdan ezilen ve sadece ona biçilen hayatı yaşayan bir varlık olarak tanımlanması, ona tercihleri hakkında söz hakkı verilmemesi Marksist açıdan feminist eleştiri ile açıklanabilir.

Toplumdaki ataerkil düzende kadın, baba evinden çıktıktan sonra bir daha o eve dönemez, bu toplumsal gerçeğin ve gücün bilincinde olan erkek bu durumu her firsatta kendi lehine kullanmaktan kaçınmaz. Bu durum, kadının hem kocasından hem de kocasının ailesinden baskı görmesine neden olur. "Şeytan, çek git dedi, ama nereye gideceksin. Bizde kocaya gittin mi bir kere, babanın evine ölün dönebilir ancak." (Buğra, 1992, s. 29). Hikâyede kaynana da ataerkil toplumdaki görevini icra eder, gelinine eziyet ettiği gibi kendi oğlunu da karşısına almaktan çekinmez. Bu durum hikâyede kadın anlatıcının gözünden şöyle anlatılır:

"Sanki gelini değil de kumasıyım. Nerdeyse geceleri de aramızda yatacak. İkide bir 'Gâvurun k1zı, sen bu eve geldin geleli beri sabuna suya para yetiremiyorum. Her gün y1kanmak! Nedir bu rezillik? Sanki bizim kocamız yok!' deyip ellerin yanında yerin dibine batırıyor beni. Utanmaz kadın, Allah'ın deresinin suyunu bile esirgiyor benden. Nasılsa oğlu benden taraf oldu. Vay sen misin karısını arkalayan? Bel küreğinin sapıyla girişti oğluna: Az kaldı gebertecekti onu. Gene de hırsını yenemedi de, attı bizi sokağa.” (Buğra, 1992, s. 29).

Kadının, kaynananın sözleri ile de aşağılandığı ve evlilik ilişkilerinde kadın ile erkeğe üçüncü şahısların doğrudan müdahale ettiği görülür. Burada kaynana ile kadının ilişkisine de dikkat etmek gerekir. Kaynananın da bir kadın olmasına rağmen kendi hemcinsi olan gelinine eziyet eder. Bunun sebebi kaynananın, kendini geliniyle özdeşleştirmesi ve gelinlik yıllarında yaşadıklarını kendi gelininde de görmeyi amaçlamasıdır. Kaynana kendi gelinlik günlerinde kendi kocasının ve kocasının ailesinin baskısına maruz kaldığ 1 günleri hatırlar. Aynı şekilde gelininin de oğlu tarafından ilgisiz bırakılmasına, baskı ve zorlamalara maruz kalmasını ister. Burada birbiri içine geçmiş iki önemli noktaya dikkat çekilmesi gerekir: Illki erkek egemen bir toplum içinden gelen kaynananın, daha önceki yaşantılarında kocasından çektiği acıların bedelini kendi oğluna hükmederek ödetmeye çalışmasıdır. 
Diğeri ise kaynananın, oğluna güven duymaması ve gelininin de kendisi gibi oğlu tarafindan aşağılanmasını istemesidir. Kaynananın hem oğluna hem de gelinine bu şekilde davranması psikanaliz açıdan feminist edebiyat eleştirisi ile açıklanır. Kaynananın ruh hali, bilinçdışında cereyan eden olaylar eleştirel bakımdan çözümlemek için kullanılır. Böylece elde edilen bulgular kaynananın kendi gelinliğinde yaşadığı, öz yaşamının derinliklerinde kalmış, özel ve gizli vakaları gün yüzüne çıkarır ve anlamlı hâle getirir. Bu nedenle kadınsal imgeleri ortaya koymak, anlamlandırmak ve sorgulamak için psikanaliz eleştiri önemli bir unsurdur.

Kaldıkları evden kovuldukları için geçim derdine düşen karı koca İstanbul'a gider, bir akrabalarının yanında kalırlar. Karı koca çalışarak biraz para biriktirir ve bir süre sonra kiraya çıkarlar. Daha sonra bir arsa alır, üstüne bir gecekondu yaptırırlar. Zamanla çiftin üç çocuğu olur. O sıralarda kocasının onu terk edeceği anlatıcının aklının ucundan bile geçmez:

"Çocuklar orda doğdu. İyiydik, geçinip gidiyorduk işte. Bu adam, beni kor da gider diye aklımın ucundan geçmezdi. Niye gitsin? Yemeği pişiyor, çamaşır yıkanıyor. Evi de, çocukları da temiz pak! Ama ben hep içeri bakmaktan, dışarıyı unutmuşum. Elin sürtükleri kol gezermiş meğer; bilemedim. Az biraz düze çıktık ya, herif azdı. Giyinip kuşanıyor, saçlarını yan yatırıp evden çıkıyor. Yarı gecelere kadar ben camlarda kalıyorum. Geldiği vakit de hiç konuşmuyor; devrilip yatıyor." (Buğra, 1992, s. 29-30).

Burada yazarın bilinçdışına ilettiği mesaj kadının; eşi, çocukları ve eviyle ne kadar iyi ilgilenirse ilgilensin, dışarıdan gelecek tehlikelerin de farkında olması gerektiğidir. Öyküde maddi yönden bir parça rahatlayan erkeğin, eşinin maddi ve manevi tüm çabalarına rağmen hemen başka heveslerin peşine düştüğü görülür. Kadının büyük bir fedakârlık ve sabır ile kocasının yolunu beklediği, kocasının ise kadının güven duygusunu hiçe saydığı belirtilir. Erkeğin sergilediği tüm davranışların normal kabul görüldügü erkek egemen toplumun ve ataerkil aile yapısının karşısında kadının, tüm benliği ile ezildiği görülür. Öyküde erkek, eşiyle tek kelime etmez, onunla bir paylaşımda bulunmaz. Bu da kadının aşağılandığının, görmezden gelindiğinin ve herhangi bir nesne olarak algılandığının göstergesidir. Anlatıcı ataerkil toplumdaki kadının erkek karşısındaki konumunu ise şöyle ifade eder:

"İkide bir konuşmamaya iyi alıştın sen. Her istediğini yapacaksın, kimse bir şey sormayacak sana! Nerde o bolluk? dedim sonunda. O da bunu beklermiş: 'İşine gelmiyorsa, işte yol: Uğurlar olsun!' dedi bana. Biz adamla pençe pençe kavga etmeye alışmamışız. Onlar höst der, biz susarız. Ninemizden anamızdan öyle gördük. Ben de sustum. Hevesini alır, havı geçer dedim; evine döner diye bekledim. Ama o hepten gitti." (Buğra, 1992, s. 30).

$\mathrm{Bu}$ durum, erkeğin bütün duygu-düşünce ve davranışlarında son derece özgür olduğunun göstergesidir. Erkek istediği kararı alır, kadın ise erkeğinin aldığı bütün kararlara -ki buna eşinin kendisini aldatması da dâhil-tahammül etmek zorundadır. Böylece kadın hem eşi hem de hemcinsi olan bir kadın tarafından âdeta kurban edilir. Kadının bu hali, onun çaresizliğinin, kadınlık gururunun hiçe sayıldığının en önemli kanıtıdır. Bütün bunlara rağmen kadının, kocasına soru sorması ve bir açıklama beklemesi, kadının bir özne olma çabasının ürünüdür. Kadın, toplumdaki yerini ve birey olma hakkını, eşine varlığıyla ve sorularıyla hissettirmeye çalışır.

Ataerkil toplum düzeninde erkek aktif/etken, kadın pasif/edilgen durumdadır. Erkek yanlış yapsa da bu durum kadın tarafından dillendirilmez, erkeğin hatasından zamanla dönmesi beklenir. $\mathrm{Bu}$ durum âdeta nesilden nesile aktarılır. Ancak kadının bu edilgen durumu, her şeyi kendi hâline bırakması istenen sonucu vermeyebilir, erkek bir daha evine dönmeyebilir. Ataerkil toplum baskısı o kadar şiddetlidir ki kadın ne kadar zor durumda olursa olsun sıkıntılarını dışarı belli etmez; baba evine dönemez, köyüne dönse bile bu kez insanların diline düşeceğinden korkar: "Üç çocukla kaldım el memleketlerinde. Ama alıp da onları köye dönmedim. Gidip de köylüyü üstüme güldürmedim: Herkesler, bir kocasına sahip olamadı diye kınayacaklardı beni.” (Buğra, 1992, s. 30). 
Erkek egemen toplum düzeninde kadının kendine özgü duygu, düşünce ve yaşamı yoktur. Kadın başkalarının düşüncelerini yaşar, davranışlarını çevresindeki insanlara göre düzenler. Aslında kadının psikolojik yönden toplum baskısı altında kalması, kadının ruhsal açıdan sömürülmesidir. Kadının içinde bulunduğu ataerkil aile yapısı, gelenek ve görenekler, örf ve âdetler, toplumsal ahlak kuralları üst yapıyı ve Marksist ideolojiyi oluşturur.

Kadın ne kadar zor durumda kalırsa kalsın ailesinin geçimini sağlar. Çocuklarının sorumluluğunu alır, çalışıp çocuklarına bakar, onları kimseye muhtaç etmez. Bu noktada kadının maddi-manevi yönden ezildiği ve yıprandığı görülür: "Zor oldu tabîi, olmaz mı? Çok sıkıntılar çektim. Gururuma yediremezdim açık açık ağlamayı da gizli gizli ağlardım. Çocuklar yaşlarımı görünce, 'Anne, niye ağlıyorsun?' diye sorarlardı. 'Yoo... ağlamıyorum; gözüme toz kaçtı' derdim. Şimdi şimdi, kızıyorum kendime: Gidenin yolu açık olsun!” (Buğra, 1992, s. 30).

Hikâyede kadın gözünden erkeklerin kadına bakış açısı da verilir. Erkek karısını terk etse, çocuklarının bakımını üstlenmese bile kadın onun namusuna laf getirmemelidir. Erkek egemen toplum anlayışında fedakârlık ve sadakat yalnızca kadına özgü değerler olarak görülür; erkeğin böyle bir sorumluluğu yoktur ve yaptığı her şey normal kabul edilir. Bu da toplumsal düzenin kadın ve erkeğe sunduğu hareket alanlarıyla ilgilidir:

"Akşamları da 'Ya, erkeğim olmadığını anlayıp biri kapıya dayanırsa, kadın başıma ben ne ederim?' diye korkumdan uyku tutmazdı gözümü. Erkek milleti işte, o senin haysiyetini iki paralık edecek, ama sen onun namusuna lâf getirmeyeceksin. Kuş uykularına dönmüştü uykularım. Çocuklar, 'Anne, ne zaman seslensek 'hı' diyorsun; hiç uyumuyor musun?' derlerdi bana.” (Buğra, 1992, s. 30).

Kadın geçimini sağlamak ve çocuklarına bakmak için çalışmak zorundadır. Bu durum yani bir insanın çalışarak geçimi sağlaması ekonomik özgürlüğü bakımından önemlidir. Ancak burada kadının para kazanmak için olağanüstü bir efor sergilediği görülür, pek çok yönden çaresizlik içinde olan kadın, bir işçi olarak sömürülür: "Hem analık hem babalık ettim onlara. Şimdi bir büroda temizlikçilik yapıyorum. İkide üçte bitiyor işim. Eve gitmeden bir iki apartmanın merdivenlerini de siliyorum. Sonra da bütün gece kemiklerim sızlıyor yorgunluktan, ama olsun!” (Buğra, 1992, s. 31).

Ekonomik bakımdan özgür olmayan ve kısıtlı imkânlara sahip olan kadın için "nikâh" kocasına karşı kullanabileceği elindeki tek kozdur, o da olmasa büsbütün ortada kalır, belki de kalacak bir yer bulamaz: "Allah'tan ev kendimizin. Yoksa hangi birine para yetirebilirdim? Adam, boşanalım, diyor. Evi versin boşanırım; ona bayıldığım yok! İyi ki nikâhım var, yoksa hâlim dumandı. Bizimki, fabrikaya girerken yaptırmıştık. Kucağımda iki çocukla çıkmıştım nikâh memurunun karşısına. Adam, 'Seyfi Kaya’yı kocalığa kabul ediyor musun?' diye soruyor. Bende tıs yok! Çünkü bizim oralarda, memurun ilk soruşunda, kız, 'he' derse çok ayıplarlar: 'Kocaya gitmeye can atarmış meğer' derler. Adam bir sefer daha sordu, ben gene ses etmedim. Bir kızdı bana: 'Hanım... Hanım! İki çocuk doğuruncaya kadar aklın nerdeydi?” (Buğra, 1992, s. 31-32). Köyden ayrilıp İstanbul'da yaşamasına rağmen içinde yaşadığı, yetiştiği toplumun kuralları kadının bilinçdışına o kadar işler ki İstanbul'da olmasına, kendisini ayıplayacak kimse olmamasına rağmen kadın yine de toplumun ne diyeceğini düşünür, kendisini psikolojik açıdan toplumsal baskı altında görür ve bu baskının altında ezilir.

Toplumun beklentisi hâlâ adamın kadına dönebileceği yönündedir. $\mathrm{Bu}$ durum kocanın yaptıklarından hiçbir şekilde sorumlu tutulmaması, ne olursa olsun kadının kocasını tekrar kabul etmesi gerektiği algısı şeklinde yorumlanır. Sosyal, kültürel ve ekonomik düzlemde ötekileştirilen, duygu ve düşünceleri hiçe sayılan kadın ikinci hatta üçüncü sınıf bir nesne konumundadır; aslında edebî metinlerde kadının hiçe sayılması, ötekileştirilmesi, bütün olayların kadın üzerinden gelişmesi ve ilerlemesi düşünülürse kadının, her ne kadar nesne olarak yer edinse de ele alınan metnin "özne"si olduğu görülür. Kadının bu şekilde ele alınması bir noktada erkeğin durumunu da konumlandırır: "Herkes, 'Sakın verme nikâhını. O, en sonunda sana döner' diyor, ama dönmez, dönmez. O kadından da üç çocuğu var. Kendi bebelerini koydu gitti, elin piçlerine babalık ediyor.” (Buğra, 1992, s. 32). 
Çocuklar küçükken babalarını sorar, onun ne zaman geleceğini merak ederler. Anlatıcı bu durumu çocuklarının henüz akıllarının ermemesine bağlar. Ancak onlar da zamanla işin iç yüzünü anlar ve babalarına karşı tavır alırlar. Erkek egemen toplum düzeninde erkek her zaman üstündür ve haklıdır. Bu nedenle erkek, kendi yaptıklarından dolayı çocukların kendisine soğuk davranmasının sorumlusu olarak kadını suçlar:

“...Ama şimdi her şeyi anlıyorlar ve onu istemiyorlar. 'Bu adamın ne işi var bu evde?' diyorlar. O da benden biliyor; "Çocuklarımı soğuttun benden" diyor... Geçende gene dövmeye kalktı beni. Çocuklar bir olup önünü kestiler: 'Sen kimsin bizim annemizi dövüyorsun?' dediler. Vurulmuş gibi çıkıp gitti. Bir daha dönmez inşallah! Bizim ona ihtiyacımız yok! En muhtaç ânımızda yüzüstü bıraktı bizi. Şimdi çocuklar meydana çıktı. Hak iddia ediyor. 'Ben babayım!' Yok canım! Hazır çocuklara kim olsa babalık eder. Onlar büyürken sen nerdeydin?” (Buğra, 1992, s. 32).

Çocukların babalarına karşı bu tutumu psikanaliz açıdan feminist edebiyat kuramıyla izah edilebilir. Anne-baba ve çocuklar arasındaki ilişki, kullanılan dil, tutum ve davranış modern psikanalizin ışı̆̆ında incelenir. Psikanaliz açıdan feminist eleştiri kahramanların ruh hallerini, bilinçdışında ve gerçek dünyada cereyan eden olayları eleştirel bakımdan çözümlemeye ve anlamlı hâle getirmeye çalışır.

Ayrıca parçada kadının "Geçende gene dövmeye kalktı beni. Çocuklar bir olup önünü kestiler: 'Sen kimsin bizim annemizi dövüyorsun?' dediler.” ifadesiyle kadının sözlü olarak şiddete maruz kalmasının yanı sıra bedenen de kocası tarafından çocuklarının ruh sağlığı hiçe sayılarak pek çok kez şiddet gördüğü ve dövüldüğü anlaş1lır. Büsbütün çaresiz ve savunmasız olan kadının erkeğin fiziksel gücünün altında ezilmesi, günümüz toplumunun da en çok üzerinde durması gereken konuların başında yer alır. $\mathrm{Bu}$ tür şiddet olaylarının önüne geçilebilmesi için bireylerin eğitilmesi ve bilinçlendirilmesi gerekir.

Anlatıcıya göre babalık sadece çocukların dünyaya gelmesine sebep olmak değildir, insanın babalık iddiasında bulunması için çocuklarını büyütmesi, onların ihtiyaçlarını gidermesi ve onlarla ilgilenmesi gerekir. Kısacası baba, maddi-manevi her yönden çocuklarının yanında olan, onlara bu gücü ve sevgiyi hissettirendir. Aksi hâlde bütün babalık hakkını kaybeder. Hikâyede dikkat edilmesi gereken bir diğer husus da babanın evi terk etmesine rağmen daha sonra evden ayağını çekmemesi, eve gelip gitmeye devam etmesidir. Kadın bu durumdan rahatsızdır, ancak ev adamın üstüne olduğu için bu durumu da kabullenmiş görünür. Adamın bu şekilde davranması ile edebiyattaki ve sosyal yaşamdaki egemenlik hiyerarşisi de gözler önüne serilir. Aynı zamanda evin erkeğe ait görülmesi, erkeğin üstünlüğünü ve ataerkil aile yapısını gösterir:

"Ah bir param olsa! Al, evini de başına çal, diyeceğim, ama şimdi ne yapayım? Aslında evi ikimiz yaptık, ama tapu üstüne onun ya, onun oldu. Yağma yok, tabiî! Bırakmayacağım onlara, yesinler! O çoktan unuttu gitti, ama ben unutmadım: Arabaya verecek paramız yoktu da, tuğlasını, kiremidini hep sırtımda taşıdım. Arkalarım cılk yara olmuştu. Haftalarca sırtüstü yatamamıştım. O kahve köşelerinde pineklerken harcını ben kardım, sıvasını ben yaptım; mal sahibi o oldu. Gelip ikide bir, beni dışarı atmaya kalkar. Allah'tan kork, rezil! Harç kırıntıları hâlâ tırnaklarımda duruyor." (Buğra, 1992, s. 33).

Hikâyede kadının sürekli çalışmak zorunda kalması Marksist bakımdan feminist edebiyat kuramı ile açıklanabilir. Kadın zulme ve haksızlığa uğrar, çocuklarıyla bir başına kalmadan önce de kendisi çalışıp emek harcarken kocası kahve köşelerinde oturur. Kadının bedenen de çok ağır işleri yapması ve erkeğin bu sırada kahve köşelerinde vakit geçirmesi, kadın ile erkeğin rollerinin değişmiş olduğunun göstergesidir. Kadın bir yandan erkek egemen toplum içerisinde manevi yönden ezilip istismar edilirken diğer yandan maddi bakımdan ağır işler altında ezilir. Hikâyede kadın; kocasına eş, çocuklarına anne, ailenin geçimini omuzlayan işçi, toplum içerisinde itaatkâr bir gelin ve hizmetçi rolleriyle sunulur. 
"Arada bir, evine temizliğe gittiğim hanım, kocamın boşanmak istediğini öğrenince, bana, 'Bizim kadınlarımız kene gibi yapışıyorlar kocalarına. Bir türlü bırakmak istemiyorlar' dedi. Nasıl gücüme gitti bilsen! Tabiî hanımefendinin tuzu kuru; kolay konuşuyor. Benim de öyle evim olsa, para getiren bir işim olsa, ben de istemem, beni istemeyen kocayı. Şeytan görsün yüzünü. Benim zorum ille de bir kocamın olması değil; başımı sokacak bir damım olsun yeter. Boşanırsam adam, bu şansı da alacak elimden. Üç çocukla ne yaparım ben? Evin yarısını bize verse, ona bile razı olacağım; ama hepsini alacağım diyen adama karşı tek silahım boşanmamak.” (Buğra, 1992, s. 33).

Kadın, erkek karşısında eksik, yetersiz ve çaresizdir; pek çok olumsuz duruma maruz kalmasına rağmen evin yarısının bile kendisine bırakılmasına razıdır. Bu sebeple tüm zorluklara göğüs gererek sırf çocuklarının hayatını idame ettirecek bir ev için çareyi, sevmediği eşinin nikâhı altında kalmakta bulur. Ayrıca evine temizliğe gittiği hanımın, evlilik hakkındaki düşünceleri dikkat çeker. Kadın, hemcinsi olan bu hanımın kendisinin hâlinden anlamayıp böyle konuşmasına üzülür. Burada ekonomik yönden rahat içinde olan kadının, erkeğin sıkıntılarını çekmek zorunda kalmadığı ve paranın bir nevi özgürlük sağladığı dile getirilir.

Hikâyede belki de tek olumlu özellik taşıyan kişi kadının çalıştığı büronun sahibidir. Kadını Bağ-kur'a üye yapmak ister, böylece kadının geleceği güvence altına alınır: "Çalıştığım büronun sahibi iyi bir insan. 'Seni Bağ-kur'a üye yapalım' diyor. Yaşlanınca, işe çıkamaz olunca üç kuruş gelirin olur. Kimselerin eline bakmazsın' Nasıl olacağımı da anlattı bana, aklım yattı. Zaten kâğıtlarımı da o dolduracak, Allah razı olsun! Eh, çocuklar da büyüyor. İnşallah babalarına çekmezler; elden ayaktan düştü diye anacıklarını sokağa atmazlar. Ben onları atmadım.” (Buğra, 1992, s. 33).

Bağ-kur'a üye olmak istemesi ve başvuru evraklarını bile bir başkasının doldurup hazırlaması, kadının eğitim durumunu öne çıkarır. Bu nedenle maddi/ekonomik gücü temsil eden erkeğin karşısında kadının, toplum içinde bir birey olabilmesi ve ekonomik özgürlüğünü elde edebilmesi için eğitim, en önemli unsurlardan biri olarak görülür. Son dönem günümüz Türkiye'sinde kadınlarda eğitim alanında büyük ilerleme kaydedilmiştir, ancak bu gelişmelerin, gelişmiş ülkelerin hâlâ gerisinde olduğu unutulmamalıdır.

\section{Sonuç, Tartışma ve Öneriler}

Tüm dünyada genellikle cinsel bir obje hâline dönüştürülen, kıyafetleri, yaşam tarzları ve eğitimleri farklı olsa da sosyal yaşamın birçok alanında bu gözle bakılan kadının, yazar olarak duyarlılı̆g 1 bir edebî eseri nasıl etkiler, bu duyarlılığın esere yansıması nasıldır, yazar olarak kadının dili, üslûbu nasıldır? Herhangi bir konuyu kadın nasıl görür, nasıl yansıtır ve kadının edebiyat dünyasındaki yeri nedir? Bütün bu sorular feminist edebiyat eleştirisinin yanıt aradığı sorulardır.

Kadın yazarların, kadın sorunlarını dile getirdikleri roman ya da hikâyeler, öncelikle yazar olarak kadına yönelik feminist eleştiri bakımından değerlendirilmelidir. Çünkü kadın yazarlar ister istemez kadınların karşılaştıkları sorunları daha çok dile getirir ve bu soruna toplumun ilgisini çekmeye çalışırlar. Hatice Bilen Buğra'nın Mal Sahibi adlı hikâyesi, kadın sorununa dikkat çekmesinin yanı sıra konuya yaklaşımı itibarıyla yazar olarak kadına yönelik feminist eleştiri bakımından incelenebileceği gibi psikanalitik ve Marksist feminist eleştiri bakımlarından da incelenebilecek özellikler taşır. Yazarın hikâyesini bir kadının ağzından anlatması, gerçeklik hissinin daha güçlü bir şekilde verilmesini sağlar. Böylece kadınların, erkek egemen anlayışının hâkim olduğu bir toplumda karşı karşıya kaldıkları sorunlar birinci ağızdan okura aktarılmış olur. Hikâyede siyasi şartların sunduğu imkânlar dâhilinde erkeğin tekelinde kalan kadın, kimliği, babası ya da eşi üzerinden tanımlanan nesne konumundadır.

Hikâyede aynı zamanda güçlü bir toplumsal eleştiri vardır. Geleneksel yapı içinde sıkışan kadının, babasının evine dönememesi, kocası tarafindan terk edildikten sonra köyüne dönerse ayıplanacağını düşünmesi, erkeğin ne yaparsa yapsın tekrar evine gelebilmesi, kadının kendi başına var olabilmesi için eğitimin önemi bu bağlamda değerlendirilebilecek konulardır. Kadının kendini düşünmeyip kocasını ve toplumu düşünmesi, kendini geri plana çekmesi, kadında kimlik sorununu ve 
kadın olma bilinci sorununu ortaya çıkarır. Bu kimlik sorunu, kadının birey olarak kendi bilincinde olmasını engeller ve ruhsal açıdan ezilmişlik duygusu içinde olmasına neden olur.

Hikâyede babalığın sadece çocuğun dünyaya gelmesine sebep olmakla olunamayacağı, babalığın çocuklarına bakmak, onlarla ilgilenmek ve geçimlerini sağlamakla olunabileceği mesaj1 çıkarılabilir. Ayrıca hikâyede erkeğin, eşine hem birey hem de kadın olma bakımından değer vermediği ve onun bağımsızlığını kısıtladığı görülür.

Kadının edebiyat sahnesine geç çıkması nedeniyle sanat eserleri, erkeklerin bakış açısıyla şekillenir ve bu eserlerde erkeklere özgü bir söylem gelişir. Bu nedenle edebiyatta yeni bir kadın dili oluşturularak kadın sorunu gündeme taşınır, bu sayede kadınlar gerek edebiyat sahasında gerek toplumsal sahada olumlu bir şekilde temsil edilmeye başlanır. Kadını başlangıçta hem okur hem de yazar olarak ele alan feminist edebiyat kuramı, zamanla edebî eserlerdeki dil ve söylem sorununa yönelir. Toplumda cinsiyet kutuplaşmasına neden olan "dil"in kalıpları kırılır ve yeni bir "kadın dili/söylemi” oluşturulur. Böylece yalnızca cinsiyeti ve doğurganlığı ile algılanan kadın, erkek egemen toplum düzeni ve ataerkil aile yapısı içerisinde yeniden kategorize edilir; kadın, nesne konumundan çıkarak özne olur.

Zaman içerisinde kadına sosyal hayatta, seçme, seçilme ve eğitim alanlarında erkeklerle eşit haklarının verilmesi, kadının ekonomik özgürlüğüne kavuşması, doğum kontrolü, çocuk büyütmenin sadece kadının sorumluluğu olmaktan çıkması gibi gelişmeler kadının sosyalleşmesini ve etkinleşmesini sağlar. Ancak toplum içinde sosyalleşen ve etkinleşen kadın, kendini gerçekleştirir; kendi bireyselliğinin ve kimliğinin farkına varır. Bu bağlamda Feminist eleştiri, erkek üstünlüğünü ve erkek merkezli toplumsal normları yıkarak kadınların özgüvenlerini geliştirmeyi ve onlara dayatılan rolleri sonlandırmayı amaçlar.

Hem birey hem de toplum olarak ötekileştirilen kadın, değişen ve gelişen dinamikler içerisinde var olmalı ve kendini yenilemelidir. Kadınlar, erkeklerin biyolojik/fiziksel üstünlüğünün zaten farkındadır, asıl önemli olan duygu, düşünce, toplumsal algı, yaşam standartları gibi noktalarda cinsiyet ayrımının yapılmaması ve bu konuda duyarlı bir bilinç geliştirilmesidir. Kadın sorunsalı, her ne zaman yalnızca kadınların omuzlarında olan bir problem olmaktan çıkar ve erkeklerin çözüm üretmeye, konuşmaya başladığı bir problem hâline gelirse işte o zaman bu sorunun çözümünde ciddi bir adım atılmış olur.

Kadının da eşine, çocuklarına ve topluma karşı birtakım sorumluluklarının olduğu, toplumun, erkeği ve kadını ile bir bütün oluşturduğu belirtilirken kadına, doğuştan sahip olduğu birey olma hakkı teslim edilmelidir. Kadına karşı bakışta toplumsal bir zihinsel dönüşüme ihtiyaç vardır. Nitelikli iş sahasında kadın istihdamı artırılmalıdır. Bireyler kadına şiddete karşı eğitilmeli; liselerde, üniversitelerde, halk eğitim merkezlerinde ve daha pek çok yerde yediden yetmişe herkese kadının toplumdaki yerini ve önemini anlatan, kadını her alanda kuşatıcı, eğitici ve bilgilendirici kurslar ve dersler verilmelidir.

Açıklamalar: Bu makale 30 Ekim-3 Kasım 2018 tarihinde IV. Uluslararası Akademik Araştırmalar Kongresi'inde sunulan sözlü bildirinin genişletilmiş hâlidir. Araştırmanın özeti sözlü bildiri olarak sunulmuş ancak tam metin olarak basılmamıştır. 


\section{Kaynaklar}

Akerson, F. E. (2010). Edebiyat ve kuramlar. İstanbul: İthaki Yayınları.

Aktaş, G. (2013). Feminist söylemler bağlamında kadın kimliği: Erkek egemen bir toplumda kadın olmak. Edebiyat Fakültesi Dergisi, 30(1), 53-72.

Argunşah, H. (1999). Kadın ve Edebiyat -1-. Kaşgar, (9), 34-40.

Argunşah, H. (1999a). Kadın ve Edebiyat -2-. Kaşgar, (10), 83-87.

Bildirici, Z. ve Gülendam, R. (2013). Buket Uzuner' in “Önceki ve Sonraki Kadın” hikâyesine feminist bir bakış. SDÜ Fen Edebiyat Fakültesi Dergisi, 30, 269-277.

Buğra, H. B. (1989). Umursanmayan kadınlar. İstanbul: Bilgi Yayınları.

Buğra, H. B. (1992). Ayın uysal ışı̆̆ı. İstanbul: Ötüken Yayınları.

Buğra, H. B. (1992). Geçmişin aynasında. İstanbul: Ötüken Neşriyat.

Eagleton, T. (2011). Edebiyat kuramı girişs. İstanbul: Ayrıntı Yayınları.

Freud, S. (2000). Psikanaliz üzerine. İstanbul: Say Yayınları.

Humm, M. (2002). Feminist edebiyat eleştirisi. İstanbul: Say Yayınları.

Kaplan, M. (2013). Hikâye tahlilleri. İstanbul: Dergâh Yayınları.

Kocabıçak, G. (2013). Tomris Uyar öykülerinin feminist eleştirisi. Yüksek Lisans Tezi, Celal Bayar Üniversitesi, Manisa.

Kolcu, A. İ. (2010). Edebiyat kuramları. Erzurum: Salkımsöğüt Yayınevi.

Kolcu, A. İ. (2006). Türk öykü dă̆arcı̆̆g 2. Erzurum: Salkımsöğüt Yayınevi.

Kolcu, A. İ. (2006). Öykü sanatı. Erzurum: Salkımsöğüt Yayınevi.

Moran, B. (1994). Edebiyat kuramlarl ve eleştiri. İstanbul: Cem Yayınevi.

Öztürk, H. (2014). Kurmaca ve gerçeklik. Ankara: Orient Yayınları.

Türker, E. A. (2003). Feminist Edebiyat Eleştirisi. Hece Dergisi Eleştiri Özel Sayısı, 77/78/79, 293305.

Selvi, Y. (2005). Feminist teori ve sanat üzerinde derrida etkisi: Yapıbozumu. www.idildergisi.com, DOI: $10.7816,79-98$.

Şen, C. (2011). Feminist edebiyat eleştirisi ve Nihan Kaya'nın Gelin hikâyesinin incelenmesi. $C B \ddot{U}$ Sosyal Bilimler Dergisi, 9(2), 448-458.

TDK (2009). Türkçe sözlük. Ankara: Türk Dil Kurumu. 


\section{Extended Abstract}

In this study, firstly, information about "feminist literary criticism", one of the literary criticism methods, was provided and then, story of Mal Sahibi by Hatice Bilen Buğra was examined according to this criticism method. Feminist literary criticism, which is considered to be one of the reader-oriented theories, starts so as to reveal the way women are addressed in literary genres and this approach against women, and manages to draw attention to other problems for women in a short time. The first starting point is to reveal male writers' point of view for women and how they address women in their works. However, feminist criticism then examines women writers and tries to determine their writing tradition, with the developments in science, technology and education. Today, it is concluded that language and discourse, which are the means of communication in the maledominant social life, are used as a tool that despises and ignores women, and attention is tried to be drawn to "women's discourse" and "women's problem." In this context, four main approaches of feminist critics to literature are mentioned: feminist criticism for women as a reader, feminist criticism for women as an author, feminist criticism in psychoanalysis, feminist criticism in Marxism / Socialism.

\section{Feminist Criticism for Women as a Reader}

In the feminist criticism for women as a reader, it is tried to be pointed out that a woman's and a man's point of view for any artwork, their reaction to the artwork and pleasure that they will take from the artwork will not be the same. In a patriarchal social order, men have a unique and sovereign point of view for the world, objects, events, things, whereas women are deemed as an object that is pushed to the second or third plan, iterated, and become estranged from the society and themselves.

The aims of this criticism are to determine the sexual ideology, woman images, woman identity, women's discourse, the type of woman and the oppression / exploitation of women both individually and socially, the position of women in the current culture, clichéd types of women, and to criticize them from the point of feminism.

\section{Feminist Criticism for Women as an Author}

In this approach, it is addressed whether women as writers have different discourses and languages from the male writers. In the male-dominant literature, women writers begin to write their works just like male writers; use male names by concealing their own identity; and apply the rules of male writers. This shows that women feel the need to obtain permission / approval from male writers and patriarchal society to write a literary work. Therefore, first of all, women artists have to create and develop a new expression language/discourse and style that can reveal women's own identities and their existence as individuals.

\section{Feminist Criticism in Psychoanalysis}

This approach addresses women from a psychoanalytic perspective both as a reader and a writer. This theory is based on researches by Freud, Jung, Adler and other psychologists. Freud sees woman as an object in the patriarchal family in a male-dominant society order. A woman needs a figure such as a father, sibling or wife in order to survive. Freud describes this situation of woman as Electra complex.

\section{Feminist criticism in Marxism / Socialism}

Marxism tries to define women by the work they do or do not do during the daily life. This method, which Marxists use to reveal art, is based on class conflict. In this context, women are seen as a labor force for a long time and a proletarian class is desired to be created from them. In the context of the male-dominance, women are seen as a thing that is bought and sold in terms of both labor force and sexual ideology, and they are exploited under this attitude. 
Hatice Bilen Buğra, who has been examined, expresses the problems of oppressed, iterated and ignored women in the city and especially in the rural areas and becomes the voice of women with her works. The sense of reality is provided more strongly as Hatice Bilen Buğra tells her story, Mal Sahibi, from a woman's mouth. Thus, the problems faced by women in a male-dominant society are conveyed to the reader from the first person. In the story, a woman who is in the monopoly of a man within the opportunities provided by the political conditions is an object defined by her identity, father or husband.

There is also a strong social criticism in the story of a woman who is struggling to make living with her three children when the man she married leaves her. The fact that a woman who is trapped within the traditional structure cannot return to the family home, thinks that she is blamed if she returns to her village after she is left by her husband, man can come home again no matter what he does, and education is important for a woman to exist by herself can be evaluated in this context. The fact that a woman does not think about herself but thinks about her husband and society, and pushes herself into the background, reveals a problem in terms of woman identity and consciousness of being a woman. This problem of identity prevents the woman from being in her own consciousness as an individual and causes her to feel mentally oppressed. 